\title{
DUKUNGAN SOSIAL DAN ADVERSITY QUOTIENT PADA REMAJA YANG MENGALAMI TRANSISI SEKOLAH
}

\author{
Dian A. Puspasari \\ Toto Kuwato \\ Hariz E. Wijaya \\ Fakultas Psikologi dan Ilmu Sosial Budaya Universitas Islam Indonesia \\ E-mail :dian_dhunkz@yahoo.com
}

\begin{abstract}
The aim of this study was to understand the relationship between social support and adversity quotient in adolescent school transition. The hypothesis of this study was "there was a relationship between social support and adversity quotient in adolescent school transition”. Subjects in this study are $7^{\text {th }}$ grade students in Sleman. All subjects are female and about 11 to 14 years old. This study used Social Supports Scale \& Adversity Quotient Scale made by researchers. The Social Support Scale refer to House's theory and the adversity quotient refer to Stoltz's theory. This study use Pearson's Product Moment Correlation to examine whether there was a correlation between social support and adversity quotient in adolescent school transition. Data analysis showed $r$ $=0.520, p=0.000(p<0.01)$ which mean that there was a very significant positive correlation between social support and adversity quotient. From the result of the study, we can conclude that social support has impact on adversity quotient in adolescent school transition.
\end{abstract}

Keywords: adversity quotient, social support, school transition.

Remaja meupakan salah tahap penting dalam perkembangan manusia. Remaja dikenal sebagai masa transisi dari masa kanak-kanak menuju dewasa. Banyak perubahan yang terjadi selama masa transisi ini, baik perubahan yang berasal dari dalam diri sendiri maupun dari luar atau lingkungan sekitar remaja tersebut. Perubahan dari dalam diri meliputi perubahan fisik, kognitif dan emosi, sedangkan perubahan dari luar diri meliputi perubahan pada lingkungan sosial.

Salah satu contoh kesulitan yang dialami oleh remaja saat menghadapi perubahan tersebut adalah kesulitan saat mereka memasuki masa transisi menuju sekolah lanjutan. Hal ini dapat terjadi pada remaja yang beralih dari tingkat Sekolah Dasar (SD) menuju tingkat Sekolah Menengah Pertama (SMP), atau remaja yang beralih dari tingkat Sekolah Menengah Pertama (SMP) menuju Sekolah Menengah Atas (SMA). Beberapa penelitian telah dilakukan untuk mengetahui dampak masa transisi ini pada diri remaja. Eccles dan Midgley (Santrock, 2002) meneliti masa transisi dari sekolah dasar ke sekolah lanjutan atau sekolah menengah pertama menemukan bahwa tahun pertama sekolah lanjutan atau sekolah menengah pertama dapat menyulitkan siswa. Misalnya persepsi remaja tentang kehidupan sekolah mereka menurun di kelas tujuh. Mereka kurang puas terhadap sekolah, kurang bertanggung jawab terhadap sekolah, atau kurang menyukai guru-guru mereka. Orientasi siswa terhadap prestasi sekolah dan kepercayaan diri dalam menyelesaikan tugas sekolah menurun saat mereka memasuki masa SMP.

Transisi dari sekolah dasar menuju sekolah lanjutan dapat menjadi sesuatu yang sangat sulit bagi remaja. Hal ini disebabkan oleh sedikitnya pengalaman remaja dalam mengatasi perubahan yang terjadi. Remaja meninggalkan lingkungan yang nyaman saat mereka berada di sekolah dasar seperti ruang kelas yang nyaman dan guru yang lebih sering dilihat oleh mereka dibandingkan orang tua mereka sendiri. Mereka biasanya menjadi anak-anak yang paling tua dan paling besar di sekolah, sedangkan saat ini 
Kesulitan dalam menghadapi masa transisi ini lebih tampak pada remaja awal dibandingkan remaja akhir. Remaja awal mengalami perubahan yang drastis dalam hampir semua aspek hidupnya. Remaja awal juga dikenal sebagai fase negatif, yaitu mudah merasakan perasaan negatif pada diri sendiri (Ahmadi \& Sholeh, 2005). Seringkali hal ini menyebabkan keputusan-keputusan yang dibuat remaja awal bersifat emosional dan menjadi tidak efektif. Remaja akhir mengalami fase yang lebih tenang daripada remaja awal. Perubahan yang terjadi pada dirinya tidak sedrastis remaja awal.

Masa transisi sekolah yang terjadi pada remaja saat mereka belum cukup me $n g$ e mbangkan k e m a m p a n menyelesaikan masalah secara mandiri, menunjukkan dampak yang lebih parah dibandingkan masa transisi yang terjadi pada tahun-tahun berikutnya. Hal ini disebabkan masa transisi ini terjadi bersamaan dengan perubahan-perubahan lain yang membutuhkan usaha adaptif besar yang membebani mereka melebihi kapasitas mereka untuk mengatasinya (Crockett, dkk, 1989). Blyth dan Simmons (Crockett, dkk, 1989) mengemukakan bahwa transisi di kelas tujuh lebih berdampak buruk daripada transisi yang terjadi di masa mendatang.

Beberapa dampak psikologis yang dapat dialami siswa saat terus-menerus gagal dalam usaha mengatasi perubahan pada masa transisi dapat berupa penarikan diri secara psikologis yang ditandai dengan berkurangnya keterlibatan dan komitmen pada aktivitas yang sedang dilakukan siswa, rendahnya tingkat partisipasi dan aspirasi di kelas, rasa terasing atau alienasi, meningkatnya ketegangan dan rasa tidak puas, bahkan siswa dapat melakukan penolakan pada pelajaran, dan menolak bersikap kooperatif(Johnson, 1970).

Jika mampu mengatasi perubahan yang terjadi pada masa transisi ini, siswa tidak hanya tumbuh menjadi pribadi yang sehat secara psikologis, namun juga menunjukkan prestasi yang bagus dalam hal pendidikan maupun bidang lainnya. Hal ini dapat terjadi pada seseorang yang mampu menolak kegagalan yang dialaminya. Seseorang yang mampu menolak kegagalan akan menunjukkan perilaku yang berlawanan dengan kondisi dirinya saat ini. Orang tersebut akan bangkit dan terus berusaha sampai dapat mencapai apa yang diinginkan atau sampai dapat mengatasi hambatan yang ada pada diri dan lingkungan sekitarnya.

Berbagai hambatan yang dirasakan oleh siswa saat memasuki jenjang pendidikan yang lebih tinggi dapat diatasi dengan adanya Adversity Quotient (AQ) pada diri siswa tersebut. Banyak faktor dari AQ yang berpengaruh terhadap kuat lemahnya daya tahan siswa dalam menghadapi situasi yang menghambat tersebut. Kinerja, bakat, kemauan, kecerdasan, kesehatan, karakter, genetika, pendidikan dan keyakinan berpengaruh terhadap AQ seseorang (Stoltz, 2005). Lingkungan mempengaruhi kinerja seseorang dalam menghadapi suatu situasi tertentu. Kinerja akan menciptakan lebih banyak kendali pada diri seseorang yang akan berdampak pada tingkat AQ seseorang (Stoltz, 2005). Hal ini menunjukkan bahwa secara tidak langsung lingkungan mempengaruhi bagaimana seseorang merespon dan menghadapi peristiwa yang dialaminya.

Carol Dweck, seorang profesor Jurusan Psikologi di University of Illinois, mengemukakan bahwa respon seseorang terhadap kesulitan terbentuk lewat pengaruhpengaruh dari orang tua, guru, teman sebaya, dan orang-orang yang mempunyai peran penting selama masa kanak-kanak (Stoltz, 2005). Hal ini menunjukkan bahwa orangtua, guru, dan teman sebaya memiliki peran penting dalam membentuk $A Q$ anak (Lestary, 2003).

Salah satu bentuk pengaruh lingkungan yang diharapkan untuk meningkatkan AQ adalah dukungan dari orang lain. Keberadaan dukungan adalah suatu hal yang penting karena dengan adanya dukungan tersebut siswa akan menjadi lebih kuat dan mereka mampu mengatasi hambatan yang ada. Siswa merasa seseorang peduli dengan apa yang sedang dihadapi oleh mereka. Mereka tidak merasa sendirian dalam menghadapi masa transisi. Hal ini sangat penting terutama bagi remaja awal 
yang cenderung lebih sulit untuk mengatasi perubahan yang ada karena masih sedikit pengalaman yang dimiliki. Napitupulu, Nashori, dan Kurniawan (2007) mengemukakan pada dasarnya setiap anak memerlukan dorongan dari orang sekitarnya apabila mereka merasa tidak mampu menghadapi masalah atau situasi tertentu.

Dukungan terhadap siswa bersumber dari dukungan keluarga, sekolah dan teman sebaya. Ketiga dukungan tersebut saling mendukung satu sama lain dan tidak dapat berdiri sendiri. Hubungan dengan keluarga, sekolah dan teman sebaya dipandang sebagai mesosistem yang membantu menghadapi tantangan dalam masa transisi sekolah lanjutan (Newman, dkk, 2007; Santrock, 2002).

Hal ini diperkuat dengan hasil penelitian yang menyebutkan bahwa dukungan sosial memiliki peran penting bagi siswa. Rendahnya dukungan sosial yang diterima oleh para siswa tersebut diduga menjadi faktor yang dapat menyebabkan gangguan dalam hal kesehatan, kepuasan hidup, dan penyesuaian diri yang positif pada kondisi yang terjadi (Newman, dkk, 2007).

Penelitian di atas menunjukkan pentingnya dukungan sosial dalam membantu remaja mengatasi hambatan di masa transisi. Dukungan sosial dapat membuat anak menjadi lebih kuat dan tahan menghadapi kesulitan. Mereka siap untuk berprestasi lebih baik dan merasa aman karena memiliki penyokong yang siap memotivasi diri mereka. Berdasarkan uraian di atas, maka muncul pertanyaan dalam penelitian ini apakah dukungan sosial memiliki hubungan dengan AQ pada remaja yang mengalami transisi sekolah.

\section{METODE PENELITIAN}

\section{Subjek Penelitian}

Subjek yang akan digunakan dalam penelitian ini yaitu siswa SMP dengan karakteristik: siswa yang duduk di kelas tujuh di daerah Sleman, berjenis kelamin perempuan dan berusia 11-14 tahun. Metode pengambilan sampel yang digunakan dalam penelitian ini adalah teknik purposive sampling yaitu teknik pemilihan sampel sesuai dengan yang dikehendaki (Latipun, 2006). Teknik ini dilakukan dengan cara menentukan kriteria subjek tertentu dan kemudian mencari subjek yang sesuai dengan kriteria tersebut.

\section{Metode Pengumpulan Data}

Pengumpulan data dilakukan dengan menggunakan dua skala, yaitu skala adversity quotient dan skala dukungan sosial. Skala AQ disusun peneliti berdasarkan teori Stoltz (2005) yang membagi kecerdasan adversity terdiri atas empat aspek, yaitu (1) Control, (2) Origin dan Ownership, (3) Reach dan (4) Endurance. Skala AQ terdiri dari 40 aitem dengan empat alternatif jawaban, yaitu: Sangat Sesuai (SS), Sesuai (S), Tidak Sesuai (TS), Sangat Tidak Sesuai (STS). Aitemaitem yang terdapat pada skala terdiri dari aitem yang bersifat favorable dan unfavorable. Pemberian skor pada aitem favorable, yaitu untuk jawaban Sangat Sesuai (SS) diberi skor empat, Sesuai (S) diberi skor tiga, Tidak Sesuai (TS) diberi skor dua, dan Sangat Tidak Sesuai (STS) diberi skor satu, sedangkan pada aitem unfavorable pemberian skornya adalah untuk jawaban Sangat Sesuai (SS) diberi skor satu, Sesuai (S) diberi skor dua, Tidak Sesuai (TS) diberi skor tiga, dan Sangat Tidak Sesuai (STS) diberi skor empat.

Sementara itu skala dukungan sosial yang mengacu pada teori dukungan sosial House Smet, 1994 terdiri atas aspek-aspek (1) dukungan emosional, (2) dukungan penghargaan, (3) dukungan instrumental, dan (4) dukungan informatif. Skala dukungan sosial terdiri dari 40 aitem dengan empat alternatif jawaban, yaitu: Sangat Sesuai (SS), Sesuai (S), Tidak Sesuai (TS), Sangat Tidak Sesuai (STS). Aitem-aitem yang terdapat pada skala terdiri dari aitem yang bersifat favorable dan unfavorable. Pemberian skor pada aitem favorable, yaitu untuk jawaban Sangat Sesuai (SS) diberi skor empat, Sesuai (S) diberi skor tiga, Tidak Sesuai (TS) diberi skor dua, danSangat Tidak Sesuai (STS) diberi skor satu, sedangkan pada aitem unfavorable pemberian skornya adalah untuk jawaban Sangat Sesuai (SS) diberi skor satu, Sesuai (S) diberi skor dua, 
Tidak Sesuai (TS) diberi skor tiga, dan Sangat Tidak Sesuai (STS) diberi skor empat.

\section{Metode Analisis Data}

Penelitian ini menggunakan uji korelasi product moment dari Pearson (Hadi, 2004). Teknik korelasi ini digunakan untuk mengetahui ada tidaknya hubungan antara dukungan sosial dan adversity quotient pada siswa kelas tujuh. Untuk pengolahan data peneliti menggunakan program komputer SPSS 12.00 for windows.

\section{HASIL PENELITIAN}

\section{Hasil Uji Normalitas}

Uji normalitas dilakukan untuk mengetahui apakah setiap variabel terdistribusi (tersebar) secara normal. Uji normalitas menggunakan teknik One Sample Kolmogorov-Smirnov Test dari program SPSS 12.00 for Windows ini diperoleh sebaran skor pada variabel adversity quotient adalah normal (K-S Z $=0.646$; $\mathrm{p}=$ 0.799 atau $p>0.05)$ dan sebaran skor pada variabel dukungan sosial adalah normal (K$\mathrm{S} \mathrm{Z}=0.824 ; \mathrm{p}=0.506$ atau $\mathrm{p}>0.05$ ). Hasil uji normalitas tersebut menunjukkan bahwa kedua skala tersebut memiliki sebaran data yang normal.

Uji linearitas digunakan untuk mengetahui apakah setiap variabel memiliki hubungan yang linear, sehingga dapat diketahui boleh tidaknya product moment digunakan untuk menguji hipotesis. Hasil uji linearitas variabel adversity quotient dengan dukungan sosial menunjukkan koefisien $\mathrm{F}=$ 18.219 dengan $\mathrm{p}=0.000(\mathrm{p}<0.05)$. Hal ini berarti bahwa hubungan antara adversity quotient dengan dukungan sosial memenuhi asumsi linearitas (membentuk garis lurus) dan kecenderungan menyimpang dari garis linearnya sebesar $\mathrm{p}=0.944$ atau $\mathrm{p}>0.05$.

\section{Hasil Uji Hipotesis}

Uji hipotesis dilakukan dengan korelasi product moment dengan bantuan komputer program SPSS 12.00 for Windows. Uji product moment dapat dilakukan karena syarat normalitas dan linearitas terpenuhi. Hasil analisis menunjukkan perolehan nilai $\mathrm{r}$ sebesar 0.520 dan $p=0.000, p<0.01$ yang berarti bahwa ada hubungan antara adversity quotient dengan dukungan sosial. Nilai $r$ yang positif, menunjukkan bahwa semakin tinggi dukungan sosial, maka semakin tinggi adversity quotient, sehingga hipotesis diterima. Sumbangan efektif dilihat dari nilai R squared sebesar $0.270 \times 100 \%=27 \%$. Hal ini berarti dukungan sosial berpengaruh terhadap adversity quotient sebesar $27 \%$.

\section{PEMBAHASAN}

Berdasarkan hasil analisis data yang diperoleh dari lapangan, terlihat bahwa terdapat korelasi antara variabel dukungan sosial dan adversity quotient. Nilai $\mathrm{r}=0.520$ berarti bahwa ada hubungan antara dukungan sosial dan adversity quotient. Nilai $r$ yang positif menunjukkan bahwa semakin tinggi dukungan sosial yang diterima, maka semakin tinggi pula AQ pada remaja. Sebaliknya, semakin rendah dukungan sosial yang diterima, maka semakin rendah pula AQ pada remaja yang mengalami transisi sekolah.

Hasil penelitian ini menunjukkan semakin tinggi dukungan sosial yang diterima siswa maka semakin tinggi pula $\mathrm{AQ}$ siswa tersebut. Hal ini sesuai dengan Carol Dweck (Stoltz, 2005) yang menyatakan bahwa respons seseorang terhadap kesulitan dipengaruhi oleh peran orangtua, guru, teman sebaya dan orang-orang penting lainnya. Pomerantz, dkk (2006) menunjukkan keterlibatan orangtua untuk membantu anak mengerjakan tugas sekolah di rumah dapat membantu anak menghindari rasa frustasi karena pengalaman kegagalan mengerjakan tugas di masa lalu, meningkatkan tanggung jawab dan keberanian anak untuk menyelesaikan tugas tersebut. Lee, dkk (1999) juga menunjukkan bahwa siswa yang menghadapi tekanan akademis yang tinggi di sekolah dan mendapatkan dukungan sosial yang tinggi di sekolah akan menyebabkan siswa mampu memenuhi target akademis tersebut dan belajar lebih banyak.

Sumber utama dukungan sosial yang diterima siswa berasal dari orangtua, sekolah dan teman sebaya. Ketiga sumber dukungan tersebut membantu siswa saat menghadapi 
seorang anak memasuki masa remaja, interaksi mereka dengan orangtua berkurang dan lebih banyak menghabiskan waktu di sekolah dan bersama teman-temannya (Santrock, 2002). Hubungan anak-anak berkembang di dalam dan sekitar sekolah, yaitu guru, teman sebaya dan orang dewasa lainnya (Lee, dkk, 1999). Hal ini memiliki kemungkinan bahwa sekolah dan teman sebaya berpeluang lebih besar dalam memberikan dukungan pada remaja tersebut. Ketiga sumber dukungan sosial tersebut ada dalam penelitian ini. Tujuannya untuk mengetahui dukungan sosial yang diterima siswa, namun penelitian ini tidak membedakan secara tegas bahwa dukungan sekolah dan teman sebaya lebih dominan daripada dukungan orangtua.

Dalam penelitian ini diperoleh sumbangan efektif sebesar $27 \%$. Hal ini menunjukkan $73 \%$ dari AQ seseorang dipengaruhi oleh faktor lain di samping dukungan sosial. Faktor-faktor tersebut berupa faktor internal individu yang mengalami kesulitan atau hambatan, yaitu kinerja, bakat, kemauan, kecerdasan, kesehatan, karakter, genetika dan keyakinan (Stoltz, 2005). Hal ini sesuai dengan Lee, dkk (1999) yang menyatakan bahwa dukungan dapat diartikan sebagai bantuan atau pertolongan atau kekuatan tambahan yang tidak bisa berdiri sendiri. Berdasarkan kategorisasi yang dilakukan, tampak bahwa tingkat dukungan sosial dan adversity quotient berada pada kategori tinggi. Pada kategori AQ, 60.3\% subjek berada pada kategori tinggi dan kategori dukungan sosial, $65 \%$ subjek berada pada kategori tinggi.

Penelitian ini melakukan perhitungan korelasi antara variabel-variabel penelitian dengan aspek-aspek yang menyusunnya. Perhitungan korelasi antara AQ dengan aspek-aspeknya, yaitu control, reach, endurance dan origin ownership dan perhitungan korelasi antara dukungan sosial dengan aspek-aspeknya, yaitu dukungan emosional, dukungan penghargaan, dukungan instrumen, dan dukungan informatif. Setelah menganalisis setiap aspek dalam variabel AQ, tampak bahwa aspek reach memiliki nilai prediktif paling besar dibandingkan aspek lainnya dan pada variabel dukungan sosial, tampak bahwa aspek dukungan emosional memiliki nilai prediktif paling besar dibandingkan aspek lainnya.

Kelemahan dari penelitian ini adalah ditemukan beberapa angket yang kelengkapan jawabannya masih kurang. Dalam skala dukungan sosial, ketiga sumber dukungan sosial tidak dibedakan secara tegas oleh peneliti dalam segi jumlah aitem, padahal sumber dukungan sosial yang diterima remaja kemungkinan besar lebih dominan dari sekolah dan teman sebaya. Hal ini menyebabkan tidak dapat diketahui sumber dukungan mana yang lebih dominan men-support siswa saat menghadapi transisi sekolah. Subjek penelitian hanya perempuan saja. Hal ini menyebabkan sulit untuk menggeneralisasikannya ke populasi yang lebih besar. Alat ukur yang digunakan masih harus disempurnakan lagi. Perlu ditambahkan cara pengisian skala di dalam angket. Tujuannya agar menghindari terjadinya kesalahan cara pengisian oleh subjek penelitian. Meskipun demikian, penulis meyakini bahwa kesalahan tersebut tidak terlalu signifikan pengaruhnya terhadap analisis data penelitian, sehingga tidak banyak berpengaruh pada hasil penelitian.

\section{SIMPULAN DAN SARAN}

Melalui penelitian ini dapat dirumuskan simpulan penelitian bahwa ada hubungan yang positif antara variabel dukungan sosial dengan adversity quotient pada remaja yang mengalami transisi sekolah. Semakin tinggi dukungan sosial, maka semakin tinggi adversity quotient pada remaja. Sebaliknya, semakin rendah dukungan sosial, maka semakin rendah adversity quotient pada remaja dalam menghadapi transisi sekolah.

Adapun saran-saran yang dapat diberikan adalah sebagai berikut:

\section{Subjek Penelitian (siswa)}

Siswa yang mengalami transisi sekolah perlu meminta bantuan orang lain mengenai cara menghadapi kesulitan saat masa transisi sekolah. Siswa dapat menceritakan masalahnya pada guru atau 
orangtua. Siswa dapat meminta dukungan dari teman-teman baiknya di sekolah agar termotivasi untuk menghadapi tantangan di sekolah.

\section{Pihak Sekolah}

Guru perlu meningkatkan perannya bukan hanya sebagai pengajar, namun juga sebagai pendamping siswa saat menghadapi transisi sekolah. Tujuannya agar siswa mendapatkan dukungan yang cukup di sekolah. Dukungan emosional dapat dilakukan dengan cara meluangkan waktu khusus untuk mendengarkan masalah yang sedang dihadapi siswa di luar jam pelajaran. Dukungan penghargaan dengan cara memberikan pujian dan ucapan selamat saat siswa mampu mengerjakan sesuatu dengan baik. Dukungan informatif dengan cara membagikan pengalaman terkait bagaimana cara beradaptasi dengan baik di sekolah, cara belajar yang efektif agar mampu menguasai suatu materi pelajaran. Dukungan instrumental dengan cara membantu siswa mengerjakan tugas yang sulit secara privat.

\section{Orang tua}

Orangtua perlu memberikan dukungan saat anak mengalami transisi sekolah dengan meningkatkan keempat aspek dukungan sosial. Dukungan emosional dengan cara memotivasi anak agar tidak mudah menyerah yang berguna bagi psikis anak saat mengalami kesulitan. Dukungan penghargaan dengan cara memberikan pujian terhadap hasil yang telah diperoleh anak baik akademik maupun nonakademik. Dukungan instrumental dengan cara membantu anak saat kesulitan dengan tugastugas sekolah. Dukungan informatif dengan cara memberikan nasehat dan arahan.

\section{Peneliti Selanjutnya}

Peneliti selanjutnya dapat meneliti AQ dengan salah satu sumber dukungan sosial yang lebih spesifik. Misalnya AQ dengan dukungan orangtua atau teman sebaya. Selain itu, dapat menghubungkan AQ dengan aspek-aspek yang bersumber dari kondisi internal individu seperti bakat, tingkat kecerdasan, karakter dan kinerja. Peneliti selanjutnya perlu mencantumkan cara pengisian skala di dalam angket untuk menghindari kesalahan pengisian skala. Peneliti juga dapat melakukan penelitian pada subjek dengan jumlah yang lebih besar dengan melibatkan subjek laki-laki dan perempuan.

\section{DAFTAR PUSTAKA}

Ahmadi, A \& Sholeh, M. (2005). Psikologi Perkembangan. Jakarta: PT. Rineka Cipta

Cobb, N.J. (2007). Adolescence: Continuity, Change, and Diversity. Boston McGraw-Hill

Crockett, L.J., Petersen, A.C., Graber, J.A., Schulenberg, J.E., \& Ebata, A. (1989). School Transitions and Adjustment During Early Adolescence. Journal of Early Adolescence, 9 (3) 181-210.

Hadi, S. (2004). Statistik Jilid 2. Yogyakarta: ANDI

Johnson, D.W. (1970). The Social Psychology of Education. New York Holt, Rinehart \& Winston Inc

Latipun. (2006). Psikologi Eksperimen. Malang: UMM Press

Lee, V.E., Smith, J.B., Perry, T.E., \& Smylie, M.A. (1999). Social Support, Academic Press, and Student Achievement: A View from the Middle Grades in Chicago. http:/ccsr.uchicago.edu/content/publ ications.php?pub_id=55/17/12/09

Lestary, L.S. (2003). Hubungan antara persepsi terhadap peran ibu dengan AQ pada remaja. Skripsi (Tidak Diterbitkan). Yogyakarta: Fakultas Psikologi \& Ilmu Sosial Budaya Universitas Islam Indonesia

Napitupulu, L., Nashori, H. F., \& Kurniawan, I.N. (2007). Pelatihan Adversity Intelligence untuk Meningkatkan Kebermaknaan Hidup Remaja Panti 
Asuhan. Jurnal Pemikiran dan Penelitian Psikologi Psikologika, 12, 43-56.

Newman, B.M., Newman, P.R., Griffen, S., O'Connor, K., \& Spas, J. (2007). The Relationship of Social Support To Depressive Symptoms During The Transition To High School. Adolescence, 167 (42), 441-459.

Pomerantz, E.M., Ng, F.F., \& Wang, Q. (2006). Mothers' Mastery-Oriented Involvement in Children's Homework: Implications for the Well-Being of Children With Negative Perceptions of Competence. Journal of Educational Psychology, 98 (1), 99-111

Santrock, J.W. (2002). Life-Span Development Jilid 2. Jakarta: Erlangga.

Smet, B. (1994). Psikologi Kesehatan. Jakarta : Gramedia Widiasara Indonesia

Stoltz, P.G. (2005). Adversity Quotient Mengubah Hambatan Menjadi Peluang. Jakarta: Grasindo 